\title{
子宮鏡下切除術にて子宮内膜癌を早期診断し追加治療が奏功した2例
}

帝京大学医学部付属溝口病院産婦人科

松見泰宇、佐渡島陽子、大貫裕子、中林 稔

竹村由里、西井 修

\section{Two cases of successful treatment of early stage la endometrial carcinoma diagnosed by hysteroscopic polypectomy}

\author{
Hirotaka Matsumi, Yoko Sadoshima, Hiroko Ohnuki, Minoru Nakabayashi, \\ Yuri Takemura and Osamu Nishii \\ Department of Obstetrics and Gynecology, University Hospital, Mizonokuchi, \\ Teikyo University School of Medicine, Kanagawa, Japan
}

\begin{abstract}
Introduction: Endometrial polyps are a common cause of abnormal uterine bleeding. In some cases, premalignant or malignant lesions are identified within polyps in a biopsy or polypectomy specimen. Hysteroscopic polypectomy, a minimal invasive surgical procedure, has the added benefit of accurate pathologic diagnosis based on complete removal of the lesion. Herein we report two cases of successful treatment of stage Ia endometrial carcinoma pathologically-diagnosed by hysteroscopic polypectomy.

Case: Case 1: A 49-year-old patient was referred to our hospital for a cervical polypoid lesion protruding from the external cervical os with abnormal vaginal bleeding. Ultrasound and MRI revealed a pedunculated endometrial polyp-like mass in the uterine cavity occupying the cervical canal. The histologic diagnosis after hysteroscopic resection showed an endometrial carcinoma (G2) confined to a small portion of the base of the polypoid lesion, with the prominent portion being a benign polyp. She underwent a semi-radical hysterectomy with bilateral salpingo-oophorectomy and pelvic and paraaortic lymphadenectomy. Case 2: A 37-year-old patient with a history of secondary infertility was referred to our hospital for selective chromotubation by hysterofiberscopy, in order to clarify the hysterosonographically-diagnosed left tubal obstruction. Hysterofiberscopic examination revealed a tiny polyp without abnormal vessels in the uterine cavity, which showed well-differentiated endometrial adenocarcinoma (G1) by hysteroscopic surgery. The patient was started on continuous oral medroxyprogesterone acetate $(600 \mathrm{mg}$ /day for 6 months), and subsequently underwent laparoscopically-assisted myomectomy, followed by ovarian stimulation with clomiphene citrate. She gave delivered a male infant by cesarean section at 37 weeks gestation, weighing $2.3 \mathrm{~kg}$.
\end{abstract}

【検索用語】子宮鏡下手術、子宮内膜ポリープ、子宮内膜癌

\section{はじめに}

子宮内膜ポリープの診断にて子宮鏡下手術後に 子宮内膜癌の診断を得たが、追加治療が奏効した 2例を経験した。1 例は子宮頝管ポリープと診断さ
れた子宮口まで突出する病変を摘出した結果、ポ リープ基部の内膜に悪性像が限局して認められた ため、根治術を追加した。 1 例は卵管閉塞が疑わ れる不妊症患者に対し、子宮鏡を施行することに より子宮内隆起病変を認め、手術後に子宮内膜癌 
を早期診断し、MPA（medroxyprogesteron acetate）療法後に妊娠に至った。術前に子宮内膜 ポリープと診断された子宮内隆起病変が、子宮鏡 下手術後に悪性であると判明する確率は緒家の報 告では0.8〜3\%である ${ }^{1-4)}$ 。悪性となるリスク因子 は、年齢 $(60$ 才以上)、閉経後、不正出血、腫瘤 径 $1.5 \mathrm{~cm}$ 以上などが挙げられている2)。子宮鏡下手 術は病変を完全に切除することが可能であること から、子宮内隆起病変が認められた場合には積極 的にこれを施行し、子宮内膜癌の診断であった場 合には適切な治療を追加する必要があることを再 認織し、この 2 例について若干の文献的考察を加 えて報告する。

\section{症例}

[症例 1 ]

[患者]49才。未経姡。結婚25才。

[家族歴及び既往歴］特記すべきことなし。

[月経歴］閉経37才。

[主訴] 不正出血

[現病歴］平成18年 9 月、不正出血を主訴に近医 受診し、子宮䅡管ポリープを指摘され当科に紹介 受診。外来にて以下の検查を施行した。

経腟超音波断層法; 子宮内膜は $19 \mathrm{~mm}$ と肥厚してい た(図 1-A)。

子宮鏡検査; 子宮頚管ポリープと思われる表面平 滑な腫瘤が子宮口から突出して扔り、子宮鏡 (OESヒステロファイバースコープオリンパス OLYMPUS HYF TYPE XP; オリンパスメディカ ルシステムズ）の子宮内腔への挿入は不可能であ った。

腹部造影MRI検查; T2強調画像でやや高信号を呈 する造影效果の乏しい細長い構造物を子宮内腔に 認めた（図 1-B)。

な㧍、前医にて施行された細胞診は以下の通り であった。

子宮内膜細胞診; class I、子宮䅡部細胞診; class II (前医)。

超音波およびMRI検查にて子宮内腔より頝管ま で連続する腫瘤を認め、悪性との確定診断が得ら れないため、子宮内膜ポリープの診断にて平成 19 年 1 月、子宮鏡下切除術を施行。

手術記録; 手術前日に子宮口を拡張するために扱 入していたラミケンRを抜去。子宮口から突出す る腫瘤と子宮口の間からレゼクトスコープ (OES 4000 ヒステロレゼクトスコープ; オリンパスメデ イカルシステムズ）を挿入。子宮内腔の底部右側
より突出する腫瘤の基部より腫瘤を切除した。 手術所見; 異型血管を認めない、表面平滑な小腫 瘤を一塊に摘出（図 2 )。

病理組織学所見; ポリープ自体は掂張した内膜腺 の増生からなる内膜ポリープで、異型は目立たな い。ポリープの基部に異型上皮があり、ポリープ とは別に切除された内膜組織に異型腺管の増生及 びback to back構造が認められた（図 3 -A, B)。

病理診断; Endometrioid carcinoma G2。

Endometrioid carcinoma G2 との病理診断の結果 に基づき、平成19年 3 月、準広沉子宮全摘術、骨 盤リンパ節郭清術を施行した。

病理組織学所見; 肉眼的に子宮後壁の内膜上にポ リープ状の突出が認められ、顕微鏡的には内膜の ポリープ状部分と、一部ポリープ状でない部分に 限局性に進展する内膜癌が認められた（図 3 -C)。 術後診断はendometorioid adenocarcinoma G1, pTlaN0M0で経過良好にて退院。外来にて経過観 察中である。

図1 症例 1 ; 画像所見;

図 1 -A）超音波断層法；子宮内膜の肥厚 $(19 \mathrm{~mm})$ を認める。

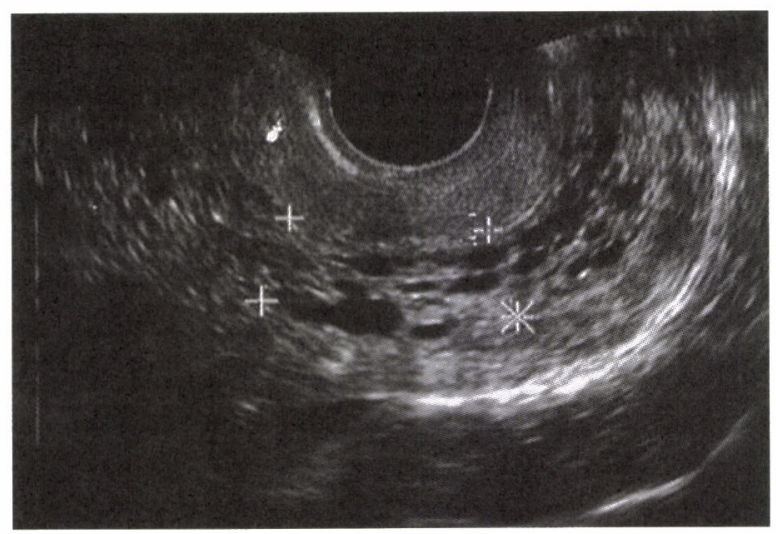

図 1 -B) MRI T2 強調画像; 造影効果の乏しい、T2強調画像でや や高信号を呈する細長い構造物を子宮内腔に認めた。

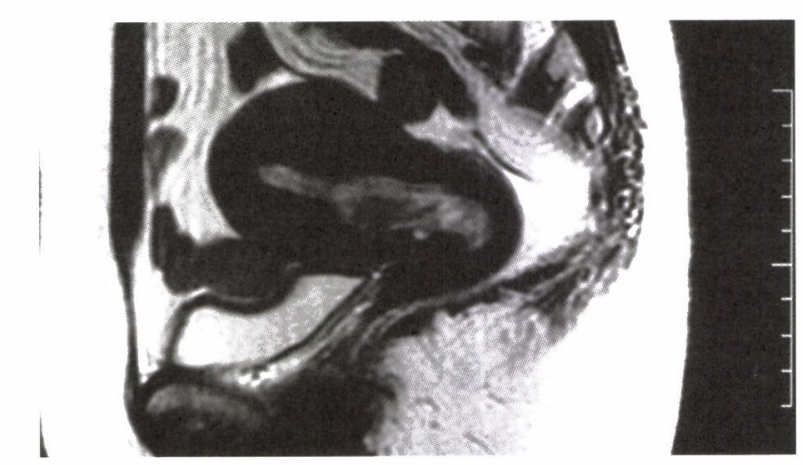


図 2 症例 1 ; 子宮鏡所見；

図 2 -A）ポリープ先端

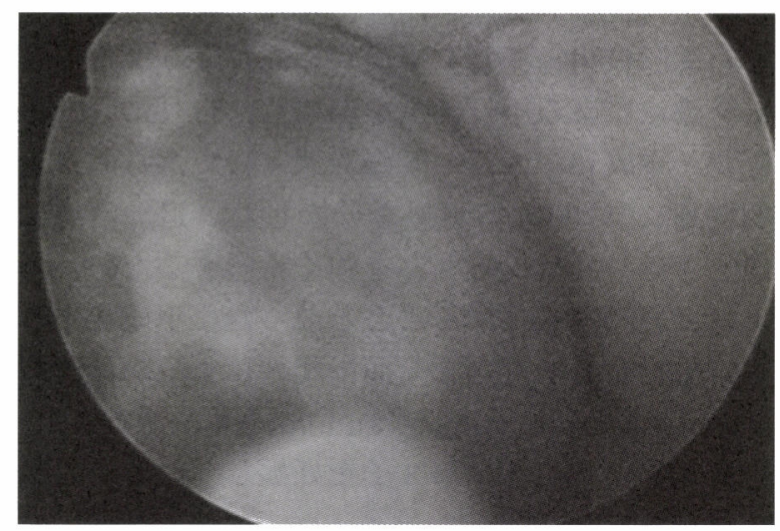

図 2 -B）ポリープ茎部；異型血管を認めない表面平滑な小腫瘤

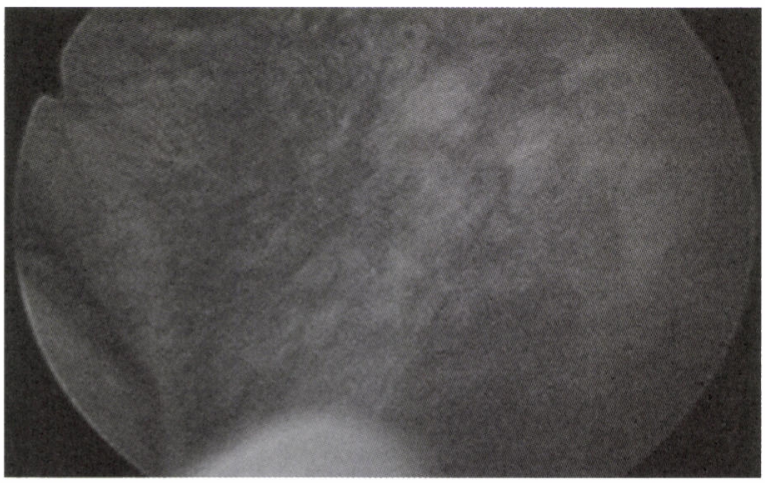

図 3 症例 1 ; 病理所見:

図 3-A）ポリープルーペ像（初回手術時）

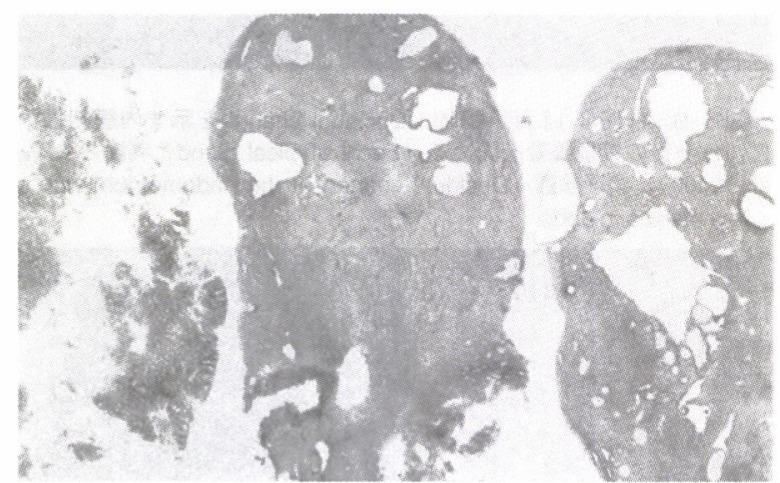

図 3-B) ポリープ基部の強拡大像；×400(初回手術時)；ポリー プ自体は拡張した内膜腺の増生からなる内膜ポリープで異型は目立 たない。ポリープと別に切除された内膜組織に異型腺管の増生及び Back to back構造が見られた。

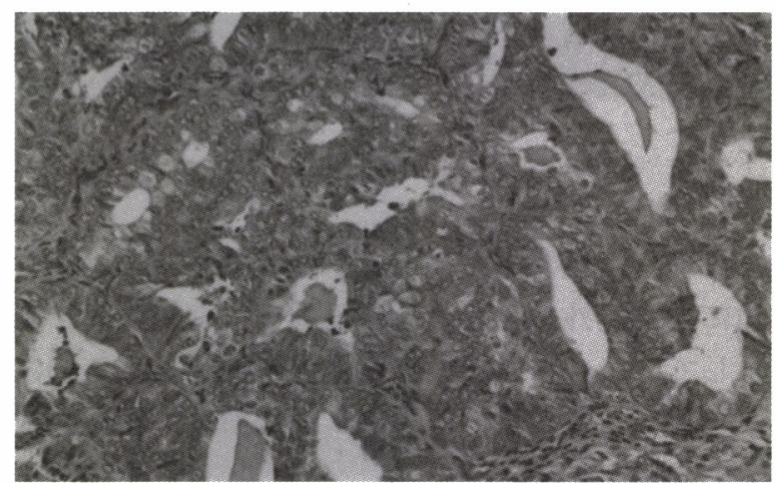

図 3-C) 摘出子宮弱拡大像; $\times 100$ (追加手術時); 肉眼的に子宮内 膜後壁にポリープ状の突出が認められ、顕微鏡的には内膜のポリー プ状部分と一部ポリープ状でない部分に限局性に進展する内膜癌が 認められた。

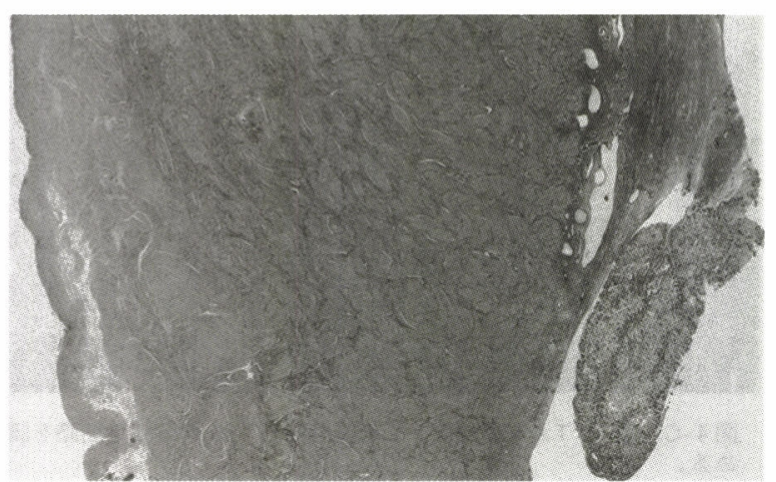

[症例 2 ]

[患者］37才。1 回経妊 0 回経産。結婚25才。 [家族歴及び既往歴］特記すべきことなし。 [月経歴］月経周期28日型、順、経時障害なし。 [主訴] 続発性不妊症

[現病歴］平成15年10月、続発性不妊を主訴に近 医受診。子宮卵管造影検査にて左卵管閉塞を認め たため、子宮鏡下選択的卵管通色素検查施行目的 に当科紹介された。なお、前医にて施行された子 宮頚部細胞診はclass Iであった。平成16年 2 月、 子宮鏡検査を施行した。子宮鏡にて内膜ポリープ と考えられる病変の内腔に突出しているのが観察 された。選択的卵管通色素検查を施行したが、左 卵管の疎通性は認められなかった。子宮鏡検查直 後に実施したsonohysterography (SHG)でも径 6 $\mathrm{mm}$ の隆起病変を認めた（図 4-A, B)。平成16年 3 月、診断的腹腔鏡及び子宮鏡下内膜ポリ一プ切 除術施行。腹腔鏡にて子宮後壁に径 $7 \mathrm{~cm}$ 大の子宮 筋腫を認めた。左卵管の疎通性は確認できなかっ た。子宮鏡下にポリープと考えられる隆起病変は 切除した。

図 4 症例 2 ; 画像所見 ;

図 4-A) HFS(hysterofiberscopy)；径 6 mm大の異型血管を認めない 表面平滑な小腫瘤

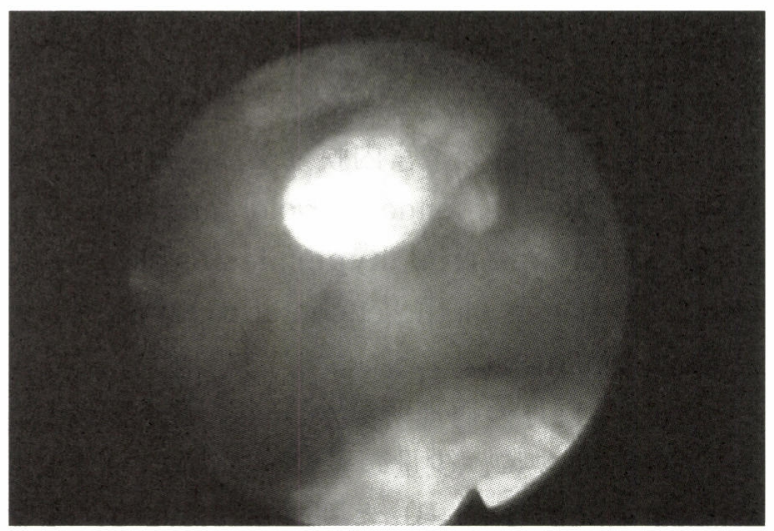


図 4 -B） SHG(sonohysterography)；小腫瘤と漿膜下筋腫を認める。

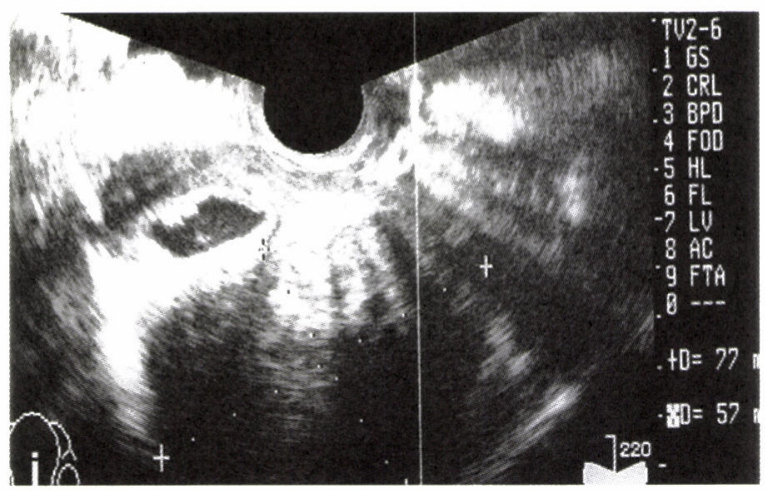

図 4 -C) MRI、T 2 強調画像; 子宮後壁に径 $7 \mathrm{~cm}$ の漿膜下筋腫を認 める。

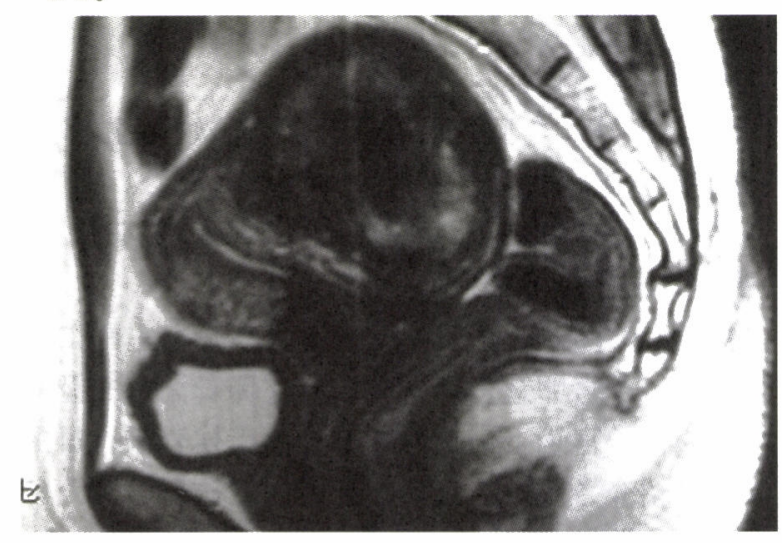

病理組織学所見: 分泌像を示唆する異型のそしい 腺構造からなる内膜組織の間に核異型、構造異型 とも高度なG1の類内膜腺癌に相当する組織を認め る(図 5 -A)。類内膜腺癌のER（エストロゲン受 容体）及びPgR（プロゲステロン受容体）は共に 陽性であった。

病理診断; endometrioid carcinoma G1。

子宮内膜ポリープと考えられた腫瘍は子宮内膜癌 であったため、平成16年 4 月、子宮内膜全面掻爬 術を施行した。腹部MRI検查を施行したが子宮後 壁に径 $7 \mathrm{~cm}$ の槳膜下筋腫を認める（図 4 -C) もの $の$ 、 endometrioid carcinoma G1 clinical stage IA との臨床診断を得た。妊孕性温存を患者が希望し たため、平成16年 5 月より MPA療法 (600mg/day) を開始し、子宮内膜全面掻爬術にて2 月月毎に治 療効果を判定する方針とした。平成16年 7 月、 9 月、11月に施行した子宮内膜全面掻爬術による病 理診断はそれぞれ、 endometrioid carcinoma G1、 atypical endometrial hyperplasia, complex. Decidual change of the endometriumwith a few atypical glandsであった。

平成16年11月の病理所見がDecidual changeを 示す内膜組織中に、少量の異型腺管を認め、Focal atypical gland（図 5 -B）と判断されたため、患者
の希望を考慮し不妊治療を再開した。平成17年 1 月、子宮後壁の漿膜下筋腫に対して腹腔鏡補助下 子宮筋腫核出術施行。平成 17 年 6 月よりクロミフ エン療法による不妊治療を開始し、11月に妊娠を 確認。平成18年 6 月、妊娠 37 週 3 日で選択的帝王 切開術にて2380gの男児を分娩した。追加治療に 関しては、妊孕性の温存を強く希望するため、外 来にて経過を観察することとなった。平成19年 2 月に施行した子宮内膜全面掻爬術による病理診断 はearly secretoryphase endometriumであった。 平成 20 年 2 月現在、第 2 子を娃娠している（妊娠 20週)。

図 5 症例 2 ; 病理所見;

図 5-A）初回手術時；分泌像を示唆する異型の乏しい腺構造からな る内膜組織の間に核異型、構造異型とも高度な $\mathrm{G} 10$ 類内膜腺癌に 相当する組織を認める。(X400)、病理診断；endometrioid carcinoma G1

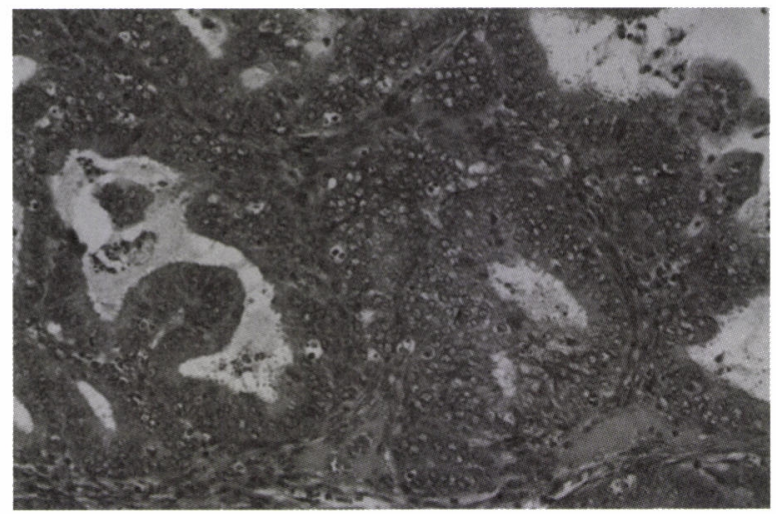

図 5 -B) $H 16$ 年 11 月手術時; Decidual change走す内膜組織中 に、少量の異型腺管を認める。Focal atypical glandと判断される。 $(\times 400)$ 、病理診断; Decidual change of the endometrium with a few atypical glands

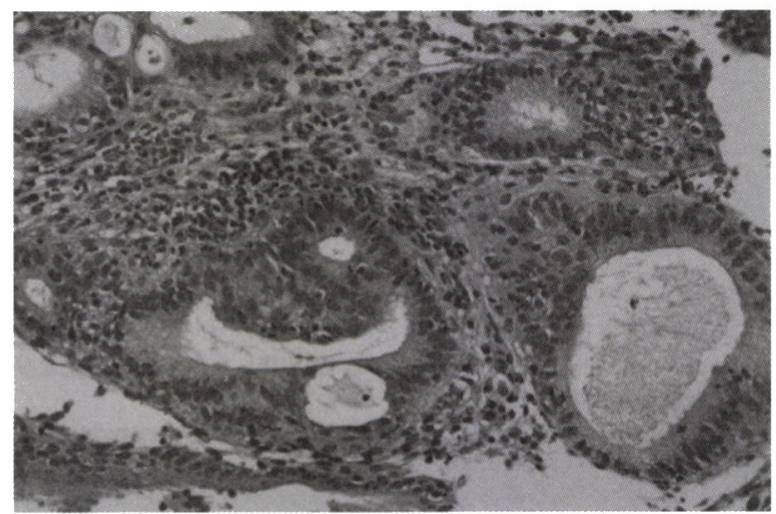

考察

当科では不妊症、不正出血のスクリーニング目 的に子宮鏡外来を開設し積極的に子宮鏡検查を施 行している。今回、子宮鏡検査を施行することに より子宮内膜癌を早期診断し追加治療に成功した 2 例を経験した。 
いずれの症例においても腫瘤は異型血管を伴わ ず、表面平滑で良性のポリープと術前診断されて いた。症例 2 では小腫瘤全体が内膜癌組織であっ たが、症例1では摘出された腫瘤径 $19 \mathrm{~mm}$ のポリー プの大部分の組織は良性のポリープであったもの の、ポリープ基部の限局された一部分の組織に異 型腺管の増生を伴う悪性像が認められた。また、 根治術により摘出された子宮の病理標本において もポリープの付着部付近の子宮内膜に限局する組 織に悪性像が認められた。

一般的に、子宮内膜癌は子宮鏡検查によって乳 頭状、結節状およびポリープ状に隆起する腫瘍と して認められるが、子宮内隆起病変を悪性として 診断するために最も重要なのは血管所見で、腫瘍 表層を走る不整血管や不整拡張血管が内膜癌の約 $80 \%$ に認められる ${ }^{5)}$ 。内膜内に限局した進行期Ia 期の癌でも、不規則走行であるが微細な異型血管 がしばしば認められるが、ポリープ状に隆起する 腫瘍の場合には、不整拡張血管が表面に巻き付く ように認められる例や血管のほとんど認められな い例もあり、診断に特に注意が必要である。ポリ ープが子宮内膜癌の術後診断となる危険因子とし て不正出血があるが、Ben-Yehudaらの不正出血を 呈する症例のみを対象とした後方視的検討でも子 宮鏡検査による所見だけでは、病理診断が子宮内 膜癌と判明した初期の子宮内膜癌の $80 \%$ は子宮内 膜增殖症と診断され、子宮内膜増殖症の正診率も 約 $50 \%$ に留まる結果となっている6)。今回提示した 症例は 2 例とも極めて初期の内膜に限局する進行 期Ia期の癌であったため、異型血管が全く認める ことができず、良性のポリープと術前診断される 結果となった。

診断精度にやや難点があるものの、不正出血や 細胞診異常などの患者に対するスクリーニング検 查として、4 方向内膜組織診あるいは子宮内膜全 面择爬と比較すると、子宮鏡検査は無麻醉でも苦 痛なく施行出来るという利点を持つことから、こ れらの侵襲度の高い検査の前にまず試みるべき検 查であると考えられる。一方、子宮鏡による直視 下の生検は、子宮内膜全面掻爬術と比較しても有 意に診断精度が高い。生検により得られた検体と 子宮鏡による生検後に子宮内膜全面掻爬術を施行 し得られた検体とを比較検討した報告では、子宮 鏡による生検後に子宮内膜全面掻爬術を施行して も正診率は向上しないと結論されている7 報告によると、子宮内膜ポリープ、子宮内膜増殖 症および子宮内膜癌のいずれかの診断が得られた
173症例の中で、子宮鏡による直視下の生検では、 病理診断を得るために有効な検体を約 $98 \%$ の症例 で採取することが可能であったのに対して、生検 後に子宮内膜全面择爬術を施行し得られた残りの 検体では、約 $87 \%$ 症例のみで病理診断が可能で あったと指摘している。この理由として子宮鏡下 切除術は病変を直視下で切除することが可能であ るため、病変の肉眼的所見が得られることととも に病変が残存する可能性が低いことがあげられる。 外来にてしばしが施行される 4 方向内膜組織診の 場合、子宮内膜全面择爬術と比較するとよりスク リーニング的意味合いが高いが、本邦での報告例 によると、本症例のようなIa期の類内膜腺癌に限 れば 4 方向内膜組織診の正診率は約70\%に留まる。 また、組織型および進行期分類で層別した場合、 類内膜腺癌でその正診率が低く、その中でも G1の 正診率はG2、G3と比較して有意に不良である ${ }^{8.9) 。 ~}$

子宮内膜ポリープが子宮鏡下手術後、悪性腫瘍 であると判明する確率は緒家の報告では $0.8 \sim 3 \%$ である ${ }^{1-4)}$ 。術前に子宮内膜ポリープと診断され、 覀性と判明する危険因子は、前述した不正出血以 外に、(1)年齢（60才以上）(2)閉経後 (3)腫瘤径 $1.5 \mathrm{~cm}$ 以上が挙げられるが ${ }^{12,10)}$ 、その他に高血圧や 肥満などの患者背景も危険因子となりうる ${ }^{3)}$ 。症 例1は閉経後、不正出血を伴い、径が $1.9 \mathrm{~cm}$ の腫瘤 であった。一方、症例 2 は上述する危険因子を全 く伴わない微少な隆起病変であった。

いずれの症例も endometrial carcinoma clinical stage Iaであったが、症例1では閉経後であったた め、子宮体癌に対する根治手術を追加し、現在ま で経過良好である。症例 2 では、患者が妊孕性温 存を強く希望したため、MPAによる高用量プロゲ スチン療法を施行し、子宮内膜組織診による治療 効果判定を繰り返したのち、内膜組織が “少量の 異型腺管を認めるのみ”の状態まで治療が奏効し たことを確認し、不妊治療を経て生児を得た。

40 才以下の若年発症例は子宮内膜癌全体の 2 $14 \%$ 占 ${ }^{11-16)}$ 、月経周期不整、無排卵、不妊症 などを主訴とする多囊胞性卵巣症候群などに代表 される卵巣機能不全を背景とする患者に好発する ことが多く、高分化型の類内膜腺癌であることが 多い。妊孕性温存療法は通常臨床進行期Ia期の患 者に対して、本邦では高用量プロゲスチン療法と してMPA 600mgの経口投与が選択されている。 治療効果判定は 2 ケ月毎の子宮内膜組織診により なされる。過去の報告における治療プロトコール が一定でないことや多数例での検討に基づいた報 
告がないことから本治療法の客観的有効性を正確 に示すのは困難であるが、特にプロゲステロン受 容体が陽性の場合の方が陰性の場合と比べて奏効 率が高い。諸家の報告によると、プロゲステロン 受容体陽性症例の患者に対する高用量プロゲスチ ン療法の奏効率は60-70\%程度であるのに対し、受 容体陰性症例の奏効率は $16-18 \%$ あるる ${ }^{17-19)}$ 。症例 2 は卵巣機能不全を伴う不妊症の患者でエストロ ゲン受容体およびプロゲステロン受容体が陽性の 若年性高分化型類内膜腺癌であり、高用量プロゲ スチン療法が奏功する典型例であった。治療効果 に関しても、2 月毎の子宮内膜組織診の結果は、 それぞれ、 endometrioid carcinoma G1、atypical endometrial hyperplasia, complex、Decidual change of the endometriumwith a few atypical glands と極めて順調な経過を辿り、排卵障害に対 する不妊治療としてクロミフェン療法を施行後、 早期に妊娠に至った。また、継続して第2子を妊 娠したことから、子宮内膜癌の再発を認めること なく子宮内膜は着床能という正常な機能を持続し ていたと考えられる。

子宮鏡検查による子宮内膜癌の腹腔内播種に関 しては、本症例のようなI期の子宮内膜癌に対して の報告を検討すると ${ }^{20-22)}$ 、腹水洗浄細胞診におい て陽性細胞が認められるリスクは増加しないとい う報告もある ${ }^{20)} も の の 、$ 疑陽性あるいは陽性細胞 が認められる頻度に焦点を絞るとそのリスクは有 意に増加する ${ }^{21.22)}$ と考えられる。従って、本症例 のように術後に悪性と診断されるような極めて初 期の病変の場合は致し方ないものの、術前に悪性 が疑われるような症例においては、腹膜播種のリ スクを念頭に入れ、子宮鏡による検査は必要最低 限度に留めるべきであると考える。

\section{おわりに}

子宮内膜ポリープの診断にて子宮鏡下手術を施 行後、子宮内膜癌との診断に至ったが適切な追加 治療が奏功した 2 例について報告した。不妊症、 不正出血、細胞診異常のスクリーニングには積極 的に子宮鏡検査を施行すること、子宮内膜ポリー プが子宮鏡にて認められた場合には、積極的に子 宮鏡下手術を施行し、覀性であった場合には適切 な追加治療を施行する必要があることを痛感した。

本論分の要旨は第20回日本内視鏡外科学会総会 （仙台）において発表した。

\section{文献}

1) Ben-Arie A, et. al: The malignant potential of endometrial polyps. Eur J Obstet Gynecol Reprod Biol 115(2): pp206-210: 2004

2 ) A. Antunes Jr, et. al: Endometrial polyps in pre-and postmenopausal women: factors associated with malignancy. Maturitas 57(4): pp415-421: 2007

3 ) Savelli L, et al: Histopathologic features and risk factors for benignity, hyperplasia and cancer in endometrial polyps. Am J Obstet Gynecol 188(4): pp927-931: 2003

4 ) Papadia A, et al: The risk of premalignant and malignant pathology in endometrial polyps: Should every polyps be resected? Minerva Ginecol 59(2): pp117-124:2007

5 ）高島英世：カラーアトラス、子宮鏡検査、悪性腫瘍(1) 子宮内膜癌、内膜癌の子宮鏡所見、金原出版、 $\mathrm{pp} 40-$ 41: 1997

6 ) Ben-Yehuda OM, Kim YB, Leuchter RS: Dose hysteroscopy improve upon the sensitivity of dilatation and curettage in the diagnosis of endometrial hyperplasia or carcinoma? Gynecol Oncol 68(1): pp4-7: 1998

7 ) Bedner R, Rzepka-Gorska I: Hysteroscopy with direct biopsy versus dilatation and curettage for the diagnosis of endometrial hyperplasia and cancer in perimenopausal women. Eur J Gynaecol Oncol 28(5): pp400-402: 2007

8 ) Ohkawara S, et al:Comparison of endometrial carcinoma coexisting with and without endometrial hyperplasia. Eur J Gynaec Oncol 21: pp573-577: 2000

9 ）上坊敏子、新井努、海野信也：産科と婦人科、産婦人 科外来マニュアル、13子宮内膜組織診での留意点、診 断と治療社、pp1478-1481: 2007

10) Giordano G, et al: Postmenopausal status, hypertension and obesity as risk factors for malignant transformation in endometrial polyps. Maturitas 56(2): pp190-197: 2007

11) Dockerty MB, Lovelady SB, Foust GT Jr: Carcinoma of the corpus uteri in young women. Am J Obstet Gynecol: 61: pp966-981: 1951

12) Crissman JD, et al:Endometrial carcinoma in women 40 years of age or younger. Obstet Gynecol: 57: pp699704: 1981

13) Gallup DG, Stock RJ: Adenocarcinoma of the endometrium in women 40 years of age or younger. Obstet Gynecol: 64: pp417-420: 1984

14) Kaku T, et al: Endometrial carcinoma in woman aged 40 years or younger: a Japanese experience. Int J Gynecol Cancer: 3: pp147-153: 1993

15) Evane-Metcalf ER, et al: Profile of women 45 years of age and younger with endometrial cancer. Obstet Gynecol: 91: pp349-354: 1998 
16) Tran BN, et al: Characteristics and outcome of endometrial carcinoma patients age 45 years and younger. Am J Clin Oncol: 23: pp476-480: 2000

17) Park RC: Principle and practice of gynecologic oncology (et Hoskins WJ, et al), Lippincott Co, Philadelpia: pp663-693: 1992

18) Creasman WT, et al: Influence of cytoplasmic steroid receptor content on prognosis of early stage endometrial carcinoma. Am J Obstet Gynecol 151: pp922-932: 1985

19) Creasman $W$, et al: Carcinoma of the corpus uteri. J Epidermiol Biostat 3: pp35-61: 1998

20) Biewenga $P$, de Blok, Birnie E: Does diagnostic hysteroscopy in patients with stage I endometrial carcinomama cause positive peritoneal washings? Gynecol Oncol 93(1): pp194-198: 2004

21) Obermair A, et al: Does hysteroscopy facilitate tumor cell dissemination? Incidence of peritoneal cytology from patients with early stage endometrial carcinoma following dilatation and curettage (D\&C) versus hysteroscopy and D\&C. Cancer 88(1): pp139-143: 2000

22) Takac I, Zegura B: Office hysteroscopy and the risk of microscopic extrauterine spread in endometrial cancer. Gynecol Oncol 107(1): pp94-98: 2007 